\title{
A major outbreak of gastroenteritis in Réunion Island in 2012: first identification of G12 rotavirus on the Island
}

N Caillère (nadege.caillere@ars.sante.fr) ${ }^{1}$, P Vilain ${ }^{1}$, E Brottet ${ }^{1}$, J Kaplon ${ }^{2}$, K Ambert-Balay $^{2}$, D Polycarpe ${ }^{3}$, L Filleul ${ }^{1}$

1. Regional Office of the French Institute for Public Health Surveillance (Institut de Veille Sanitaire), Saint-Denis, Réunion, France

2. National Reference Centre for Enteric Viruses, Dijon, France

3. Health Agency of the Indian Ocean, Saint-Denis, Réunion, France

Citation style for this article:

Caillère N, Vilain P, Brottet E, Kaplon J, Ambert-Balay K, Polycarpe D, Filleul L. A major outbreak of gastroenteritis in Réunion Island in 2012: first identification of G12 rotavirus on the Island. Euro Surveill. 2013;18(19):pii=20476. Available online: http://www.eurosurveillance.org/ViewArticle.aspx?Articleld=20476

Article submitted on 08 April 2013 / published on 09 May 2013

Between August and November 2012 a severe outbreak of gastroenteritis occurred on Réunion Island, affecting more than 50,000 cases, particularly young children. Virological analyses showed that the virus responsible for this epidemic was rotavirus. Genotyping of stool samples indicated circulation of rotavirus type $\mathrm{G}_{3} \mathrm{P}[8]$ but also $\mathrm{G}_{12} \mathrm{P}[8]$, highlighting the risk of global emergence of this genotype in the coming years.

On Réunion Island, a French overseas administrated territory located in the south-western Indian Ocean, gastroenteritis outbreaks are usually observed during the austral winter, between the months of August and November. While outbreaks of gastroenteritis had been of moderate severity on the island between 2008 and 2011 [1], an intense epidemic occurred in 2012. Monitoring has been in place for several years, involving many professionals and coordinated by the Indian Ocean Regional Office (Cellule de l'InVS en region Océan Indien: Cire OI) of the French Institute for Public Health Surveillance. This system allowed to detect in mid-August 2012 an unusual increase in gastroenteritis cases that exceeded seasonal averages, and to inform the public health authorities and the population in a reactive way.

\section{Population and healthcare} system on Réunion Island

Réunion Island is located in the south-western Indian Ocean, at 5,900 miles from France and 500 miles from Madagascar, with a population of 830,000 inhabitants in 2012. The population is younger than in mainland France. In $2010,41 \%$ of the population was younger than 25 years, and only $11 \%$ were older than 60 years. Medical facilities are similar to those in France, and there are more than 890 general practitioners and more than 80 pediatricians distributed throughout the island, as well as four hospitals and six emergency departments.

\section{Surveillance system}

Gastroenteritis surveillance on Réunion Island is based on different complementary systems:
A syndromic surveillance system is based on all emergency departments (ED) on the island (Organisation de la surveillance coordonnée des urgences (OSCOUR) network). Data are collected daily directly from patients' computerised medical files that are filled in during medical consultations at ED [1-3]. Among the collected variables, the diagnosis is categorised according the 1oth revision of the international Classification of Diseases (ICD-10)[4]. Several indicators are routinely monitored, including the number of ED visits for gastroenteritis (ICD-10 codes Ao8 and Ao9).

A network of sentinel general practitioners of Réunion Island reports every week the numbers of consultations for acute diarrhoea $[1,5]$. A case of acute diarrhoea is defined as a patient having more than three liquid stools per day during the past 15 days and motivating consultation.

The national health insurance centre of Réunion Island (Caisse générale de sécurité sociale; CGSS) sends to the Cire Ol every week the numbers of consultations made by general practitioners and paediatricians of the island. These consultation data, coupled with those from sentinel practitioners, allow to estimate by extrapolation the total weekly number of consultations for acute diarrhoea on the whole island $[1,6,7]$.

Three sentinel hospital laboratories report to the Cire OI the monthly percentage of samples positive for rotavirus, adenovirus and norovirus to ensure virological surveillance of viral gastroenteritis. In addition, a selection of rotavirus-positive samples was sent, as

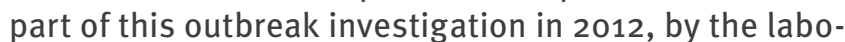
ratories of the hospitals of Saint-Denis and Saint-Pierre to the National Reference Centre for Enteric Viruses in order to determine the $G$ and $P$ genotypes of rotavirus strains. Genotyping was performed by RT-PCR according to the EuroRotaNet protocol [8-14] and confirmed by sequencing the partial $\mathrm{VP}_{7}$ and $\mathrm{VP}_{4}$ coding genes.

A surveillance of deaths possibly related to gastroenteritis is achieved via monitoring of death certificates 
Weekly visits to emergency departments for gastroenteritis, Réunion Island, 2012 versus mean numbers in 2010 and $2011(n=3,732)$

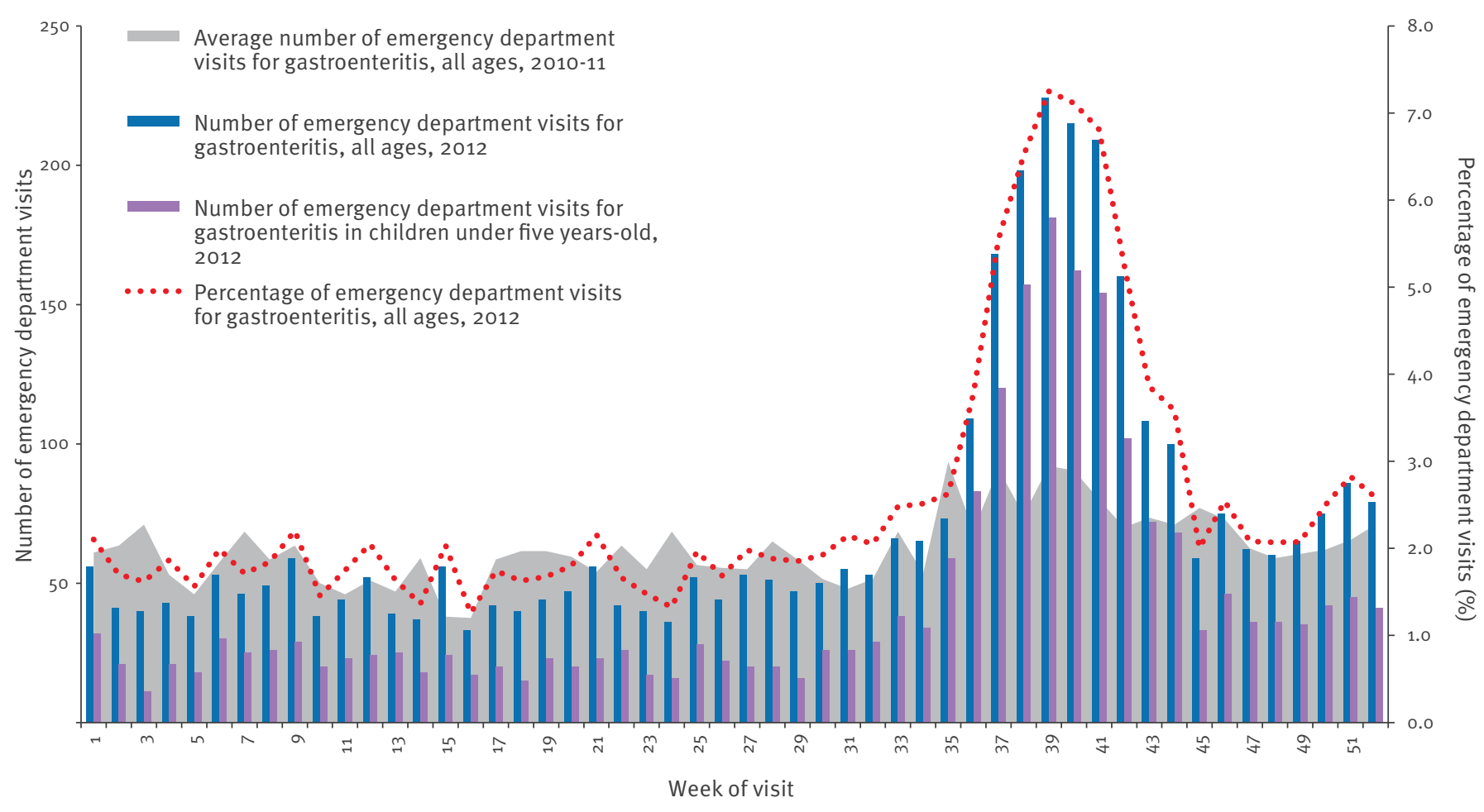

Sources: Institut de veille sanitaire (InVS) - Cellule de l'InVS en région (Cire) océan Indien / Organisation de la surveillance coordonnée des urgences (OSCOUR).

received by the Health Agency of the Indian Ocean (Agence de Santé Océan Indien; ARS OI).

Each week, data from these different surveillance systems are collected, validated, analysed and interpreted. During outbreaks, a weekly epidemiological report is written, presenting the results of these analyses and the appropriate recommendations.

\section{Outbreak description}

In 2012, an increase in gastroenteritis cases on Réunion Island was detected in week 33 (week starting 13 August) by the OSCOUR network (Figure 1). During that same week, the percentage of consultations for acute diarrhoea reported by sentinel practitioners was about $2.1 \%$, exceeding the seasonal average of $1.6 \%$. Analysis of the data by age showed that children five years-old and younger were most affected throughout the epidemic period (Figure 1). In fact, $73 \%$ of ED visits for gastroenteritis were observed among children of this age.

According to the two surveillance systems, the outbreak peak was reached in week 39 (last week of September). During that week, more than 230 ED visits for gastroenteritis were recorded, representing more than $7 \%$ of the total attendance. Among these 230,187 involved children aged five years and younger, representing $27 \%$ of the total attendance for this age group. Moreover, for the same week, the percentage of consultations for acute diarrhoea identified by sentinel practitioners was $6 \%$ and the total number of consultations for this pathology on the whole island was estimated to be nearly 8,000 .

Over the entire outbreak period from week 35 to week 44, nearly 1,600 ED visits for gastroenteritis were recorded, and it was estimated that more than 53,500 general practitioner consultations for acute diarrhoea took place on the whole island. Among the ED visits for gastroenteritis, $74 \%$ were concerning children aged five years and younger; $56 \%$ of them were boys.

The virological surveillance rapidly revealed high rates of samples positive for rotavirus. Retrospective analysis of weekly data showed an increase in this rate at the end of July, the rate exceeded more than $30 \%$ in week 33 (week starting August 13). The peak was reached in week 36 (first week of September), with a value of $44 \%$ 
Weekly percentage of samples positive for rotavirus, hospital laboratories Saint-Denis, Saint-Paul, Saint-Benoît, Réunion Island, week 27-44 2012

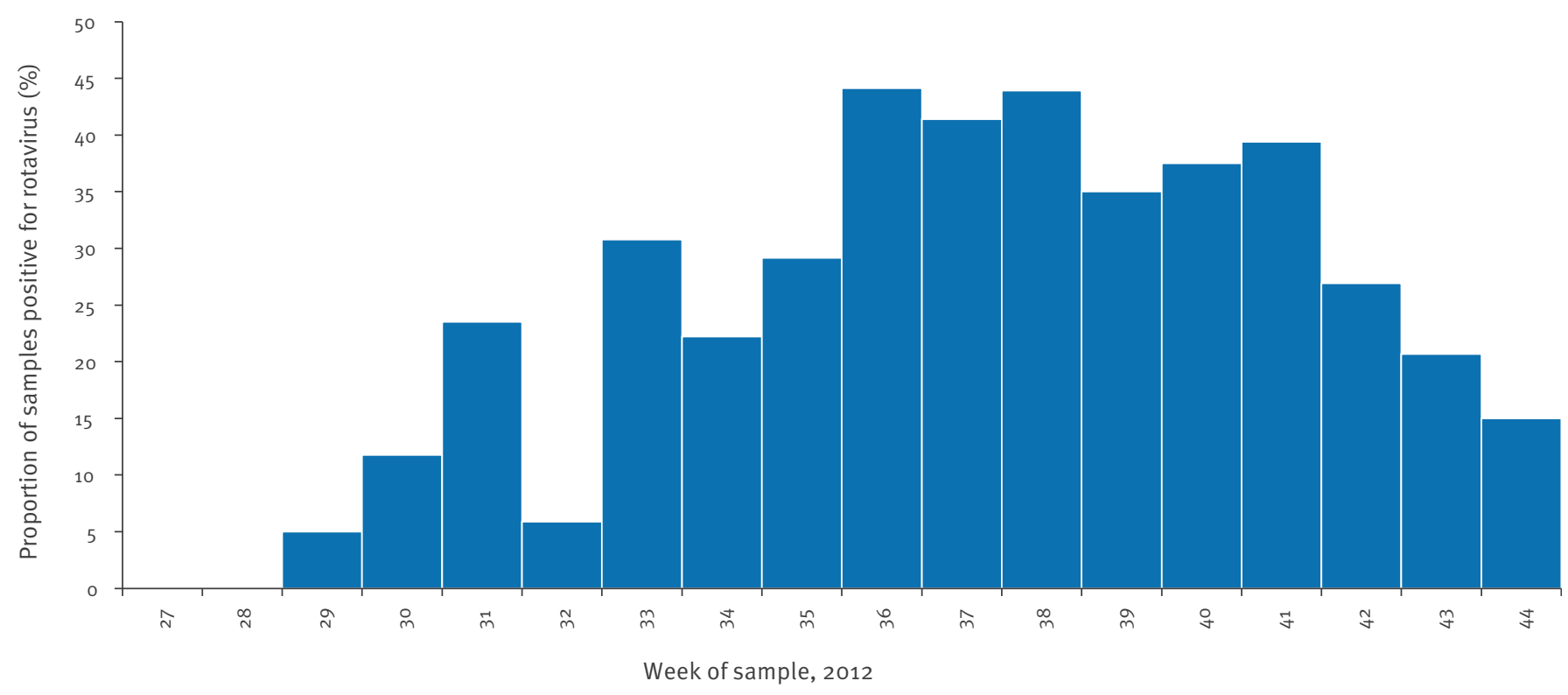

Sources: Institut de veille sanitaire (InVS) - Cellule de l'InVS en région (Cire) Océan Indien / Laboratories of the hospitals of Saint-Denis, Saint-Paul, Saint-Benoît, Réunion Island.

(Figure 2). This rate was maintained at a level greater than $35 \%$ before declining gradually after week 41 .

Percentages of samples positive for adenovirus and norovirus were lower $(7 \%$ and $3 \%$, respectively, from July to October), suggesting that the outbreak of gastroenteritis was mainly due to the circulation of rotavirus on the island. In December, genotyping of 20 rotavirus-positive samples, randomly selected, was carried out by the National Reference Centre for Enteric Viruses. Four of them were genotype $\mathrm{G}_{12} \mathrm{P}[8]$, one was a co-infection of genotypes $\mathrm{G}_{12}, \mathrm{G}_{1}$ and $\mathrm{G}_{3}$ associated with $P[8]$, and the 15 others were $\mathrm{G}_{3} \mathrm{P}[8]$ strains. Phylogenetic analysis of the partial VP7 coding gene revealed that the $\mathrm{G}_{12}$ strains from the Réunion Island clustered in lineage III (Figure 3).

During the whole outbreak period, six death certificates mentioning gastroenteritis as one of the potential causes of death were identified. Three of them involved children younger than two years, and the other three affected individuals older than 70 years. One child and one elderly person died of dehydration, the other two children had underlying medical conditions, and the other two elderly people were suffering from comorbidities such as diabetes and hypertension.

\section{Discussion}

The surveillance based on networks from different health providers on Réunion Island highlighted an outbreak of gastroenteritis of unusual intensity, which lasted about 10 weeks, extending from late August to early November 2012. This outbreak was characterised by intense circulation of rotavirus and a high proportion of young cases, as well as by its severity, reflected in the occurrence of several deaths. This underlines the importance of not neglecting this risk when such epidemics occur.

This study reports for the first time the occurrence of the $G$ and $P$ genotypes of rotavirus strains on Réunion Island and revealed circulation of rotavirus genotype G12 at a significant level (5/20), although the high activity of rotavirus observed on the island does not seem to be the result of a high prevalence of this emerging genotype only. The G12 strains from Réunion Island clustered in lineage III, as previously observed for G12 strains from other European countries and worldwide. According to the National Reference Centre for Enteric Viruses, G12 genotypes circulated with a low prevalence of $3.5 \%$ during the previous season in mainland France (data not shown), but their emergence as the most prevalent rotavirus genotypes has 
Phylogenetic tree based on the partial amino acid sequences (280 aa) of the rotavirus G12 VP7 coding gene, gastroenteritis outbreak Réunion Island, 2012

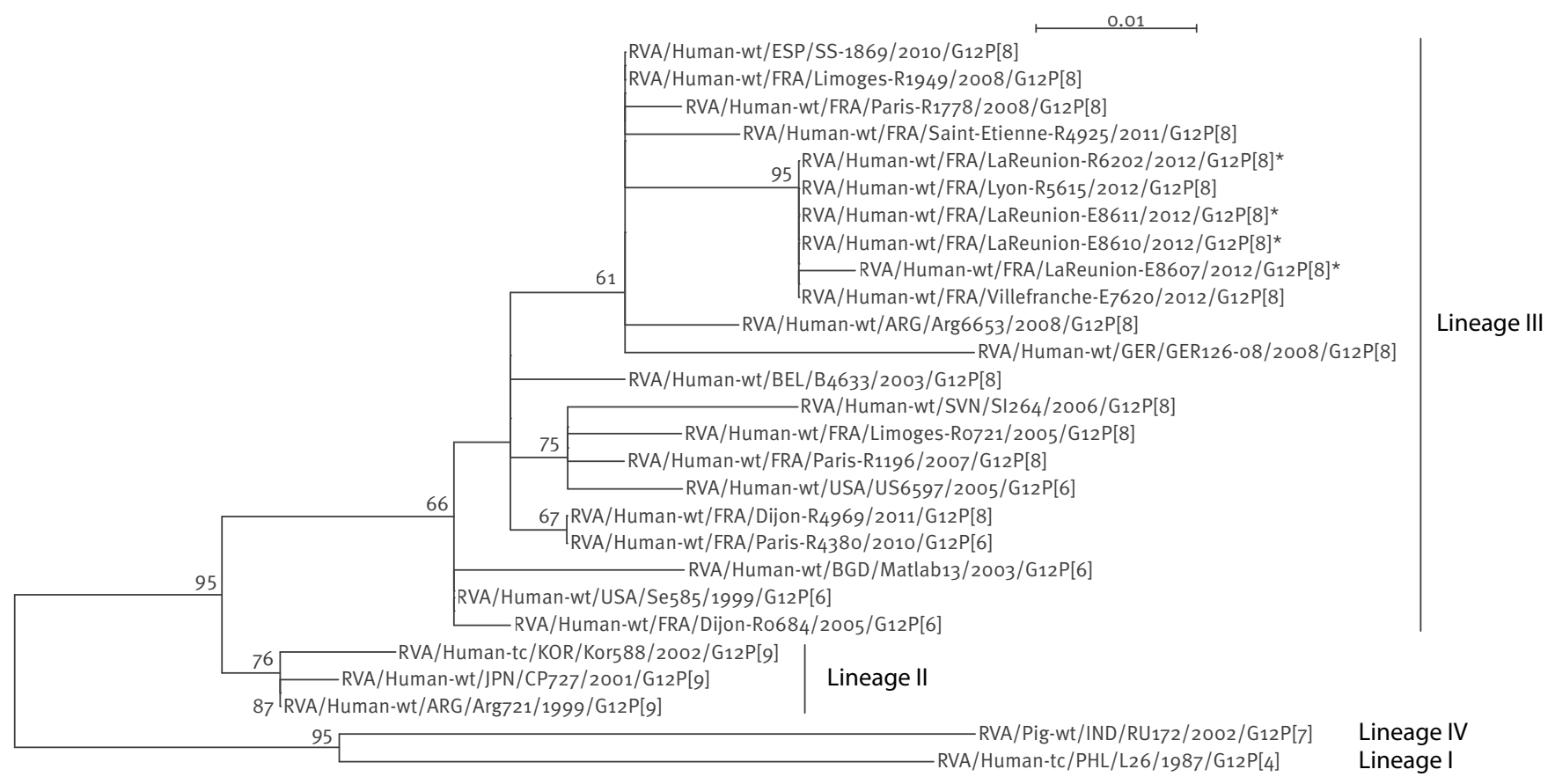

Phylogeny was reconstructed using the maximum-likelihood method implemented in the PhyML programme with the Jones Taylor Thornton substitution model. Number of substitutions per site is indicated by the scale bar. Bootstrap values were calculated for 500 replicates and are indicated at each node when $\geq 60 \%$. Strains from Réunion island are indicated with an asterisk.

Sequences of the French RVA G12 strains were submitted to the European Nucleotide Archive database (http://www.ebi.ac.uk/ena/) under the following accession numbers: HF952906 to HF952917, HM035517 and HM035518.

GenBank accession numbers of the reference strains used for this analysis are: RVA/Human-tc/PHL/L26/1987/G12P[4]: M58290; RVA/Humanwt/ARG/Arg721/1999/G12P[9]: EU496254; RVA/Human-wt/JPN/CP727/2001/G12P[9]: AB125852; RVA/Human-tc/KOR/Kor588/2002/G12P[9]: EU496259; RVA/Human-wt/ESP/SS-1869/2010/G12P[8]: JQ410021; RVA/Human-wt/ARG/Arg6653/2008/G12P[8]: JNo88450; RVA/Human-wt/ GER/GER126-08/2008/G12P[8]: FJ747618; RVA/Human-wt/BEL/B4633/2003/G12P[8]: DQ146643; RVA/Human-wt/SVN/Sl264/2006/G12P[8]: DQ995173; RVA/Human-wt/USA/US6597/2005/G12P[6]: FJ152121; RVA/Human-wt/BGD/Matlab13/2003/G12P[6]: DQ146676; RVA/Human-wt/ USA/Se585/1999/G12P[6]: AJ311741; RVA/Pig-wt/IND/RU172/2002/G12P[7]: DQ204743.

been recently demonstrated in several regions of the world such as Nepal [15], Spain (Basque Country) [16], Argentina (Tucuman, Catamarca and Rio Gallegos) [17] and Nigeria [18], and we can assume that this genotype could emerge globally in the coming years. The impact of the rotavirus $\mathrm{G} 12$ is not documented in these countries, except in the Spanish study, where it is claimed that the impact of the rotavirus $\mathrm{G}_{12}$ epidemic in the Basque Country was high, with the rate of hospitalisation similar to previous seasons in which rotavirus $\mathrm{G}_{1}$ or $\mathrm{G} 9$ were dominant [16].

Efficacy trials of the two licensed rotavirus vaccines (Rotarix, GlaxoSmithKline and RotaTeq, Merck) focused on the rotavirus $\mathrm{G}$ genotypes most prevalent across the world, i.e. $\mathrm{G}_{1}, \mathrm{G}_{2}, \mathrm{G}_{3}, \mathrm{G}_{4}$ and $\mathrm{G}_{9}$, and data on their efficacy against rotavirus $\mathrm{G}_{12}$ are very limited. In a recent study, Rotarix vaccine demonstrated efficacy against severe gastroenteritis caused by $\mathrm{G}_{12}$ rotavirus [19]. Nevertheless, it should be emphasised that knowledge about vaccine efficacy against the $\mathrm{G}_{12}$ genotype is limited and there is a need for further study. However, in our study conducted in Réunion Island, G12 genotype was associated with $P[8]$. Since the $P[8]$ genotype is present in both licensed vaccines, these vaccines should be effective against these $\mathrm{G}_{12} \mathrm{P}[8]$ strains.

\section{Acknowledgements}

We acknowledge all the partners involved in the surveillance of gastroenteritis in Réunion Island: The sentinel general practitioners, Dr Arnaud Bourdé, Emergency Department, University Hospital Centre of Saint-Denis, Réunion, France, Dr Yves Jacques Antoine, Emergency Department, Hospital Group of Saint-Benoît, Réunion, France, Dr Katia Mougin Damour, Emergency Department, Hospital Centre of SaintPaul, Réunion, France, Dr Pierre-Jean Marianne Dit Cassou, Emergency Department, University Hospital Centre of SaintPierre, Réunion, France, Dr Marie-Christine Jaffar Bandjee, Microbiology Laboratory, University Hospital Centre of SaintDenis, Réunion, France, Dr Pierre Colbalchini, Microbiology Laboratory, Hospital Group of Saint-Benoît, Réunion, France, 
Dr Gérard Martigny, Biology Laboratory, Hospital Centre of Saint-Paul, Réunion, France, Dr Alain Michault, Laboratory for Bacteriology, Parasitology, Virology and Hospital Hygiene, University Hospital Centre of Saint-Pierre, Réunion, France, GCS Tesis, Brigitte Ristor, National Health Insurance Center of Réunion Island, Céline Fremy, National Reference Center for enteric viruses, Dr Nathalie Jourdan-Da Silva, French Institute for Public Health Surveillance.

\section{Authors' contributions}

Nadège Caillère has made contributions to the epidemiological analyzes, to the interpretation of results and to the writing of the manuscript. Pascal Vilain has made contributions to the epidemiological analyzes, to the interpretation of results and to the writing of the manuscript. Elise Brottet has made contributions to the epidemiological analyzes and interpretation of results and has been involved in revising the manuscript critically for important intellectual content. Jérôme Kaplon has made contributions to the virological analyzes, to the interpretation of results of virological analyzes and to the writing of the manuscript. Katia Ambert-Balay has made contributions to the virological analyzes, to the interpretation of results of virological analyzes and to the writing of the manuscript. Dominique Polycarpe has been involved in revising the manuscript critically for important intellectual content. Laurent Filleul has made contributions to the interpretation of results of epidemiological analyzes, and to the writing of the manuscript.

\section{Conflict of interest}

None declared.

\section{*Authors' correction}

Bootstrap values and lineages were added to the figure on 13 May 2013.

\section{References}

1. Filleul L. Le développement de la surveillance épidémiologique à la Réunion et à Mayotte. [The development of epidemiological surveillance in Reunion Island and Mayotte]. Bulletin de veille sanitaire, 2012;15:8-17. French. Available from: http://www.invs.sante.fr/fr/Publications-et-outils/ Bulletin-de-veille-sanitaire/Tous-les-numeros/Ocean-indienReunion-Mayotte/Bulletin-de-veille-sanitaire-ocean-Indien.-N15-Numero-special-Fevrier-2012

2. Caillère $N$, Fouillet $A$, Henry V, Vilain $P$, Mathieu $A$, Raphaël $M$, et al. La surveillance des urgences par le réseau OSCOUR $®$ (Organisation de la surveillance coordonnée des urgences). [The surveillance of emergencies by the OSCOUR® network (Organisation of the coordinated surveillance of emergencies)]. Saint-Maurice: Institut de Veille Sanitaire; 2012. 12 p. French. Available from: http://www.invs.sante.fr/fr/Publicationset-outils/Rapports-et-syntheses/Autres-thematiques/2012/ La-surveillance-des-urgences-par-le-reseau-OSCOUR-ROrganisation-de-la-surveillance-coordonnee-des-urgences

3. Carrillo-Santisteve P, Ambert-Balay K, Arena C, Poujol I, Caillère N, Delmas G, et al. Epidémies hivernales de gastroentérites aiguës en France, bilan de trois saisons (2006/2007, $2007 / 2008$ et $2008 / 2009$ ). [Winter outbreaks of acute gastroenteritis in France, results for three seasons (2006/2007, $2007 / 2008$ and 2008/2009)]. French. Bull Epiémiol Hebd. 2010;31-32:349-52. Available from: http://www.invs.sante.fr/ beh/2010/31_32/beh_31_32_2010.pdf

4. World Health Organization (WHO). International Statistical Classification of Disease and Related Health Problems, Tenth Revision (ICD-10). Geneva: WHO; 2004. Available from: http:// www.who.int/classifications/icd/en/

5. Brottet E, Renault P, Larrieu S, Jaffar-Bandjee MC, Rachou $E$, Polycarpe $D$, et al. Implication du réseau de medecins sentinelles dans la surveillance des maladies infectieuses à la Réunion. [Involvement of the network of sentinel general practitioners in the surveillance of infectious diseases in Réunion Island]. Bulletin de veille sanitaire. 2010;7:2-4. French. Available from: http://www.invs.sante.fr/fr/Publicationset-outils/Bulletin-de-veille-sanitaire/Tous-les-numeros/
Ocean-indien-Reunion-Mayotte/Bulletin-de-veille-sanitaireOcean-Indien-Reunion-Mayotte-n-7-Septembre-2010

6. Vilain $P$, Caillère $N$, Larrieu $S$, Ristor $B$, Filleul L. Utilisation des données de l'assurance maladie pour la surveillance syndromique à la Réunion. [Using data from health insurance fo syndromic surveillance in Réunion Island]. Bulletin de veille sanitaire. 2012;17:10-14. French. Available from: http://www.invs.sante.fr/Publicationset-outils/BEH-Bulletin-epidemiologique-hebdomadaire/ Derniers-numeros-et-archives/Archives/2011/BEH-n-31-2011

7. Baroux N, Ristor B, Ferdinand P, Renault P, Filleul L. Utilisation des données de la Caisse Générale de Sécurité Sociale de la Réunion dans le cadre de la surveillance non spécifique. [Using French national health insurance data for nonspecific monitoring on Reunion Island]. Rev Epidemiol Sante Publique. 2011;59(5):319-25. http://dx.doi.org/10.1016/j. respe.2011.04.005 PMid:21940126

8. European Rotavirus Network. European Rotavirus Network 2013 [Accessed 5 Apr 2013]. Available from: http://www.eurorota. net/docs.php

9. Gómara MI, Cubitt D, Desselberger U, Gray J. Amino acid substitution within the $\mathrm{VP}_{7}$ protein of $\mathrm{G}_{2}$ rotavirus strains associated with failure to serotype. J Clin Microbiol. 2001;39(10):3796-8. http://dx.doi.org/10.1128/JCM.39.10.37963798.2001 PMid:11574622 PMCid:88438

10. Gouvea V, Glass RI, Woods P, Taniguchi K, Clark HF, Forrester $B$, et al. Polymerase chain reaction amplification and typing of rotavirus nucleic acid from stool specimens. J Clin Microbiol. 1990;28(2): 276-82. PMid:2155916 PMCid:269590

11. Iturriza-Gomara M, Kang G, Gray J.. Rotavirus genotyping: keeping up with an evolving population of human rotaviruses. J Clin Virol. 2004;31(4): 259-65. http://dx.doi.org/10.1016/j. jcv.2004.04.009 PMid:15494266

12. Simmonds MK, Armah G, Asmah R, Banerjee I, Damanka S, Esona M, et al. New oligonucleotide primers for P-typing of rotavirus strains: Strategies for typing previously untypeable strains. J Clin Virol. 2008;42(4):368-73. http://dx.doi. org/10.1016/j.jcv.2008.02.011 PMid:18378188

13. Gentsch JR, Glass RI, Woods P, Gouvea V, Gorziglia M, Flores J, et al. Identification of group A rotavirus gene 4 types by polymerase chain reaction. J Clin Microbiol. 1992;30(6):136573. PMid:1320625 PMCid:265294

14. Iturriza-Gomara M, Green J, Brown DW, Desselberger U, Gray JJ. Diversity within the VP4 gene of rotavirus $P[8]$ strains: Implications for reverse transcription-PCR genotyping. J Clin Microbiol. 2000;38(2):898-901. PMid:10655412 PMCid:86240

15. Ansari S, Sherchand JB, Rijal BP, Parajuli K, Mishra SK, Dahal RK, et al. Characterization of rotavirus causing acute diarrhoea in children in Kathmandu, Nepal, showing the dominance of serotype G12. J Med Microbiol. 2013;62(Pt 1):114-20. http:// dx.doi.org/10.1099/jmm.0.048124-0 PMid:23038804

16. Cilla G, Montes M, Gomariz M, Alkorta M, Iturzaeta A, PerezYarza EG, et al. Rotavirus genotypes in children in the Basque Country (North of Spain): rapid and intense emergence of the G12[P8] genotype. Epidemiol Infect. 2013;141(4):868-74. http:// dx.doi.org/10.1017/So950268812001306 PMid:22873952

17. Stupka JA, Degiuseppe JI, Parra GI. Increased frequency of rotavirus $\mathrm{G}_{3} \mathrm{P}[8]$ and $\mathrm{G}_{12} \mathrm{P}[8]$ in Argentina during 2008-2009: whole-genome characterization of emerging G12P[8] strains. J Clin Viro.l 2012;54(2):162-7. ttp://dx.doi.org/10.1016/j. jcv.2012.02.011 PMid:22410133

18. Oluwatoyin JM, Adeyemi AO, Famurewa O, Svensson L, Nordgren J. Molecular epidemiology of rotavirus and norovirus in Ile-Ife, Nigeria: high prevalence of G12P[8] rotavirus strains and detection of a rare norovirus genotype. J Med Virol. 2012;84(9):1489-96. http://dx.doi.org/10.1002/jmv.23343 PMid:22825829

19. Steele AD, Neuzil KM, Cunliffe NA, Madhi SA, Bos P, Ngwira B, Witte D, Todd S, Louw C, Kirsten M, Aspinall S, Van Doorn LJ, Bouckenooghe A, Suryakiran PV, Han HH. Human rotavirus vaccine Rotarix ${ }^{\mathrm{TM}}$ provides protection against diverse circulating rotavirus strains in African infants: a randomized controlled trial. BMC Infect Dis. 2012 Sep 13;12:213. http:// dx.doi.org/10.1186/1471-2334-12-213 PMid:22974466 PMCid:3462149 